\title{
Truth Tampering Through Social Media: Malaysia's Approach in Fighting Disinformation \& Misinformation
}

\author{
Moonyati Mohd Yatid ${ }^{1}$
}

\begin{abstract}
Though poorly defined and highly politicized, the term 'Fake News' has been popularized by the Trump administration in recent years. Scholars prefer to use terms such as Information Disorder, in particular Disinformation and Misinformation, to discuss this global concern. The dissemination of disinformation and misinformation is not new. However, the penetration of social media and messaging applications today enable such information to spread much faster, deeper and wider. Further, social media and messaging applications have become the public's source of primary information. These platforms are fast-becoming a birthplace of the manipulation of truth and the influencing of public opinion. The advancement of technology has also been manipulated to create false information and add to the severity of the problem. The impact of disinformation and misinformation varies: from financial difficulties faced by businesses to influencing the outcome of elections to physical violence triggered by racial and religious tensions. This paper aims to explore: 1) How information disorder, in particular, disinformation and misinformation, are being disseminated through social media and instant messaging platforms to influence public opinion; 2)How states respond to disinformation and misinformation; 3) Malaysia's disinformation and misinformation landscape and 4) Key areas for Malaysia to improve on, namely enhancing its current legal responses, developing digital literacy, heightening the accountability of social media platforms and strengthening the fact-checking mechanism.
\end{abstract}

Keywords: Disinformation, Misinformation, Social Media, Content Regulation, Fake News

${ }^{1}$ Institute of Strategic and International Studies (ISIS) Malaysia. Corresponding e-mail: moonyati@isis.org.my 


\section{Moonyati Mohd Yatid}

\section{Introduction}

The term "Fake News", has been gaining the attention from societies all over the world since the end of 2016. For instance, There has been a spike in the usage of the term by leaders around the world (Gabbatt, 2018). A search on Google of the term in November 2018 showed 702,000,000 results. However, the catch-all term is not only poorly defined, but also highly politicalised by the Trump administration against journalists and news organisations who disagree with their perspective (Lind, 2018; Morin, 2018; Wardle \& Derakhshan, 2017; Wendling, 2018). It does not stop there - over the past year more than 20 global leaders have also used the term to accuse journalists of spreading lies (Lees, 2018).

Although the colloquial term is widely used, it is only a fraction of a larger phenomenon called Disinformation and Misinformation, which are under the umbrella of 'Information Disorder'. The three types of Information Disorder are described below (Wardle \& Derakhshan, 2017), according to First Draft News, the truth-seeking non-profit based at Harvard's Shorenstein Centre.

1. Misinformation: Information that is false, but not created with the intention of causing harm

2. Disinformation: Information that is false and deliberately created to harm a person, social group, organisation or country

3. Mal-information: Information that is based on reality, used to inflict harm on a person, organisation or country

Further, there are several ways to categorise disinformation and misinformation (Shu, Sliva, Wang, Tang, \& Liu, 2017; Tandoc Jr, Lim, \& Ling, 2018; Wardle \& Derakhshan, 2017). One that is defined by eavi Media Literacy for Citizenship (Steinberg, 2017), a non-profit organisation that guides citizens in this challenging media environment, has also been adopted by Malaysia's Cyber Defence Operations Centre (Centre, 2018). This model describes the 10 categories of misleading news as 1 ) Propaganda 2) Clickbait 3) Sponsored Content 4) Satire and Hoax 5) Error 


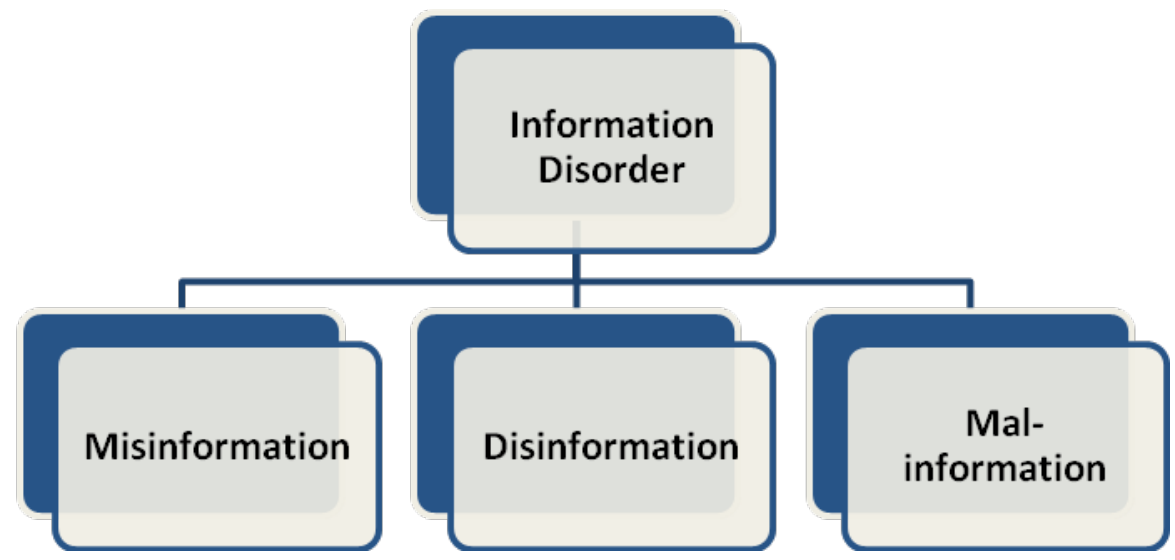

Figure 1. Types of Information Disorder (Source: Wardle \& Derakhshan, 2017, p. 20)

6) Partisan 7) Conspiracy Theory 8) Pseudoscience 9) Misinformation and 10) Bogus. eavi also describes the motivation behind those misleading news either due to money, politics or power, humour, passion and (mis)inform. Further, the organisation also categorised the level of impact, from neutral to high, for those ten categories. Four categories fall under "high impact", they are conspiracy theory, pseudoscience, misinformation and bogus. The details of the categorisation are described in Figure 2.

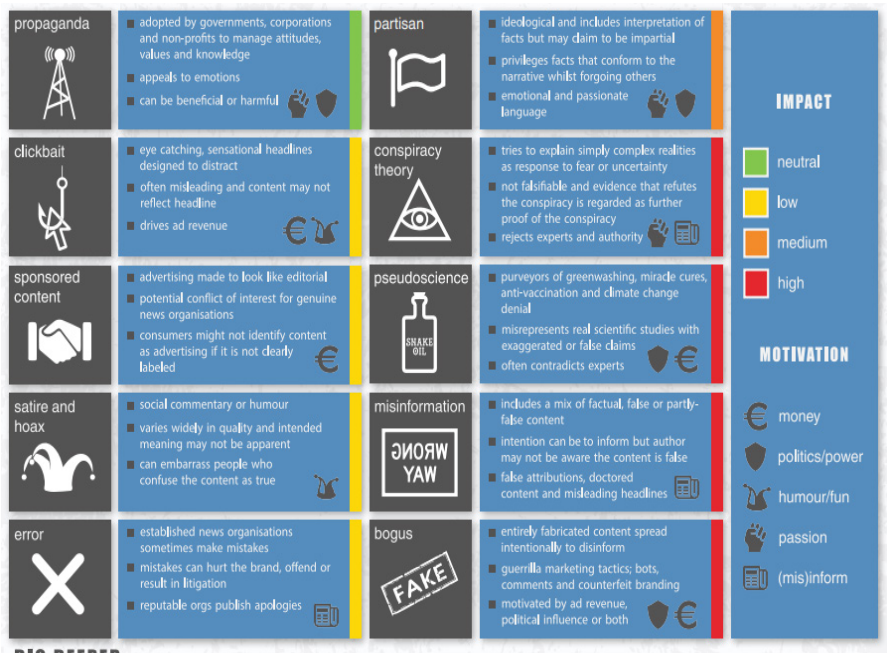

Figure 2. Categories of Disinformation and Misinformation

(Source: Steinberg, 2017) 


\section{Moonyati Mohd Yatid}

This paper aims to answer 3 main research questions, thus they will be presented and discussed in three sections. Section 1 focuses on Information Disorder on Social Media. Section 2 focuses on States Responses in Countering Disinformation and Misinformation and lastly Section 3 focuses on Malaysia's Perspectives: Digital Landscape, Misinformation Trend and current Approaches as well as the way forward for Malaysia.

\section{Information Disorder on Social Media}

In this section, the paper will provide discussion based on three sub-sections. First is on the rise of social media, followed by the breadth and speed of false information and lastly on the implications of online false information.

\section{Rise of Social Media}

According to the Global Digital Report (GDR) 2018, while the world's population today is at 7.593 billion people, more than half of the population, which is about 4.021 billion people, are internet users (WeAreSocial \& Hootsuite, 2018). The growth in internet users is largely due to affordable smartphones and mobile data plans. In 2017, more than 200 million people own their first mobile device, making about 5.135 billion people now possess a mobile phone and the global mobile internet users is about $49 \%$ of the total population. In India for instance, while only $60 \%$ of all households have access to basic sanitation, $88 \%$ of India's households own mobile phones, according to the 'Household Survey on India's Citizen Environment \& Consumer Economy' (ICE 360 survey) conducted in 2016 (Economy, 2016).

The GDR 2018 also found that active social media users are about 3.196 billion people, which is a $13 \%$ increase (362 million people) since January 2017 (WeAreSocial \& Hootsuite, 2018). Further, both WhatsApp and Facebook Messenger also grew twice as fast as the core Facebook platform, with the number of people using each of the messaging 
application up by $30 \%$ year on year (WeAreSocial \& Hootsuite, 2018). Today, not only is the penetration of social media much larger than any states, its function too has transformed to be more powerful in influencing the people. While the intent of social media and instant messaging platforms initially was to socialise with friends and family, these platforms have revolutionised their function to become a primary source of information (Nic Newman with Richard Fletcher \& Nielsen, 2018; WeAreSocial \& Hootsuite, 2018).

\section{Breadth and Speed}

Disinformation and misinformation is a problem happening in both social media and instant messaging platforms, and the ways they are being disseminated differ. In open networks such as Facebook and Twitter, it could be observed that people rely on public opinion to avoid social isolation. According to the "Spiral of Silence" Theory, people do not share about policy issues and moral components if they think their point of view is not widely shared (Gearhart \& Zhang, 2014; Noelle-Neumann, 1974). Thus, popularity cues such as likes, comments, and retweets could be deciphered as endorsements of opinions, thus encouraging the public to share their opinions on these platforms. Further, the existence of Bots, which is software that imitates human behaviour by posting, liking or retweeting automatically, also triggers the sharing of public opinions. Bots are, however, being used to pump out information that is typically false and misleading. In closed and private networks, such as WhatsApp, encryption makes the public feel like it is a "safer place" for them to engage in discussions involving sensitive issues within their community and without attracting attention of the authorities, especially in authoritarian countries. Further, according to The Illusory Truth Effect, which is a mental strategy involving our implicit memory or memory of the past - every time a reader encounters false stories, the story will grow more familiar and casts the illusion of truth (Hasher, Goldstein, Toppino, \& behavior, 1977). 


\section{Moonyati Mohd Yatid}

Human biases also play a role for misinformation to tap into society's minds. This is because, humans react to content that knocks on the grievances and beliefs that we currently possess, thus seditious posts will generate quick engagement (Meserole, 2018). In an analysis on US presidential campaign, it was revealed that top fake election news stories initiated more total engagement on Facebook than top election stories from 19 major news outlets combined (Silverman, 2016).

Technology advancement could also be manipulated to support the dissemination of misinformation, although unintentionally. "Algorithmic Curation" involves automated selection of what content should be displayed to users, what should be hidden, and how it should be presented. This is especially dangerous when social media filter bubbles rank a fake story on top. One situation is through the algorithms on social media platforms where posts are displayed based on "relevance" instead of reverse chronological order. This means that the algorithm will prioritise posts with contents that are of greater prior engagement - further disseminating online falsehood. This algorithm is practiced by Twitter, but also Facebook and YouTube. Ultimately, when human bias is combined with these algorithms, social media platforms emerge as confirmation bias machine (Meserole, 2018). A study found that it took the truth about six times as long as falsehood to reach the same amount of people (Vosoughi, Roy, \& Aral, 2018). The truth, do not gain the same amount of attention as the false.

Besides the influence of algorithms, the manipulation of technology contributing to disinformation could be observed by Deep Fakes, which involves photos and videos that realistically replace one person's face with another. The danger of this is that anyone can be made to appear as doing or saying anything (Baker \& Capestany, 2018). Anyone can also deny their actions to this kind of fakery. Another technology that plays a role in creating and spreading disinformation are Bots and "Algorithmic Curation". The former involves software that could imitate human behaviour - it is capable to post, like or retweet 
automatically. Most of the time, bots are used to pump out information, many of which are false and misleading. A study has also found that it is hard for users - ordinary users or experts - to detect texts written by bots (Oliver, 2018). Even though it is easier to deceive users when the subjects of false information are non-factual, such as entertainment, and factual topics like science, also manage to deceive a high number of users: $30-40 \%$ of automated texts deceive ordinary users while 15$25 \%$ deceive experts. The research also found that information disliked by the crowd has a higher deception rate of $10-15 \%$ for both ordinary users and experts.

It also does not help that publishers of false information are driven by a strong financial motive. During the US Election Campaign period, an enormous amount of websites publishing false information were traced to a small city in Macedonia, where its teenagers were vigorously creating false controversial stories to gain massive income through advertising (Subramanian, 2017).

\section{Implications of Online False Information}

In recent years especially, online information almost always involves factors tampering with the truth. Content regulation is a way to manage the impacts of misinformation. While some countries uphold "Freedom of Speech" to protect the voice of its people, some prefer to opt for the content regulation model. Content regulation could either be controlled by states or guided by states. While many argue that content regulation suppress the freedom of expression, it is vital to manage and ensure that the information ecosystem remains harmonised and society is not under threat due to the mismanaged information shared online.

Disinformation and misinformation influence the opinion of the public and bring various threats to society. False information could ruin the reputation of people and organisations, influence election outcomes, financially impact businesses, and create or further intensify racial and religious tensions, which could escalate into violence. False information 


\section{Moonyati Mohd Yatid}

that leads to violence could be observed in several countries including India, Myanmar and Indonesia - mostly amplifying people' fear of madeup crimes or intertwined with Hate Speech (Azali, 2017; Head, 2017; Lamb, 2018c; PTI, 2018; Safi, 2018; Sanghvi, 2018).

In India, for instance, many of its people are first-time Internet users. Many have fallen prey to disinformation, mostly through the WhatsApp instant messaging platform. The false information spread online are mostly crime-related, especially on child lifting rumours (Saldanha, Rajput, \& Hazare, 2018) and others include rumours on gang robbery and organ trafficking. All of which have disastrously prompted fearful mobs to kill numerous innocent people and stoking ethnic and religious hatred an ill-informed public (PTI, 2018; Sanghvi, 2018). In one mob, 9 men were attacked with wooden sticks by more than 1,500 villagers on mere suspicion after false stories circulated online (PTI, 2018). According to IndiaSpend analysis, 33 persons have been killed and at least 99 injured in 69 reported cases, between $1^{\text {st }}$ of January 2017 until $5^{\text {th }}$ of July 2018 (Saldanha et al., 2018). The growing number of people being killed and mob attacks have shaken the Indian government: in some areas, the internet was briefly shut down to stop disinformation from spreading further and deeper (Burgess, 2018). Police also tried to warn people in the villages not to believe the rumours (Bengali, 2018), but their speed was no match for WhatsApp.

\section{States Responses in Countering Disinformation and Misinformation}

There are at least 35 countries where their governments are taking actions against disinformation and misinformation, directly or indirectly (Funke, 2018). However, the focus of the intervention may differ - foreign disinformation campaign, election interference, hate speech, political bots, Deep Fakes and advertising, media literacy or just misinformation in general. Table 1 describes the different country approaches. 
Truth Tampering Through Social Media

Table 1. States Approaches in Combatting Disinformation and Misinformation

\begin{tabular}{|c|c|c|}
\hline State & Action & Focus \\
\hline Australia & Government task force & Election interference \\
\hline Bangladesh & Bill and arrests & Propaganda and misinformation \\
\hline Belarus & Law & Misinformation \\
\hline Belgium & $\begin{array}{l}\text { Expert group and informational } \\
\text { website }\end{array}$ & Misinformation \\
\hline Brazil & $\begin{array}{l}\text { Proposed government } \\
\text { task force, } 20 \mathrm{draft} \\
\text { bills and platform agreements }\end{array}$ & Election-related misinformation \\
\hline Cambodia & Law & Misinformation \\
\hline China & Laws and reporting portal & Misinformation \\
\hline Croatia & Draft Bill & Hate Speech and misinformation \\
\hline Denmark & $\begin{array}{l}\text { Task force, brochures and } \\
\text { government action plan }\end{array}$ & Misinformation and media literacy \\
\hline Egypt & Law and arrests & Misinformation \\
\hline France & Bill & Election misinformation \\
\hline Germany & Law & Hate Speech \\
\hline India & $\begin{array}{l}\text { Database and proposed state } \\
\text { law }\end{array}$ & Misinformation \\
\hline Indonesia & $\begin{array}{l}\text { Government task } \\
\text { forces, arrests, site } \\
\text { tracking and press briefings }\end{array}$ & Misinformation \\
\hline Ireland & Bill & Political bots and advertising \\
\hline Italy & $\begin{array}{l}\text { Online reporting portal and } \\
\text { arrest }\end{array}$ & Misinformation and fake reviews \\
\hline Kenya & Law & Misinformation \\
\hline Malaysia & Law & Misinformation \\
\hline Myanmar & Law and arrests & Misinformation \\
\hline Nigeria & Media literacy campaign & Media literacy \\
\hline Pakistan & Government Twitter account & Misinformation \\
\hline The & Dismissed Bill & Misinformation \\
\hline Philippines & & \\
\hline Russia & Bill & Misinformation \\
\hline Saudi Arabia & Government threats & Misinformation \\
\hline Singapore & Parliamentary report & Misinformation \\
\hline South Korea & $\begin{array}{l}\text { Government task force and } \\
\text { proposed amendments }\end{array}$ & Misinformation \\
\hline Spain & Committee recommendation & Misinformation \\
\hline Sweden & $\begin{array}{l}\text { Proposed government } \\
\text { authority }\end{array}$ & Foreign disinformation campaigns \\
\hline
\end{tabular}




\begin{tabular}{lll}
\hline Taiwan & Bill & Misinformation \\
Tanzania & Blog licensing & Media regulation \\
Turkey & Investigation & Misinformation \\
Uganda & Social media tax & Internet regulation \\
United Arab & Government threats & Misinformation \\
Emirates & & \\
United & Parliamentary report and task & Misinformation and foreign \\
Kingdom & force & disinformation campaigns \\
United & Proposed federal law, platform & Political ads, foreign \\
States of & testimonies, failed state & disinformation, general \\
America & advisory group, state & misinformation, media literacy \\
& law and threat assessment & and deep fake videos \\
\hline
\end{tabular}

(Source: Funke, 2018)

Among the role model countries that serve as an interesting case study is Germany. In January 2016, a fake story about a Russian-German girl who was allegedly raped, dominated the headlines for several weeks - manipulating public opinion and causing conflicts. Known as the "Lisa Case", it was one of the most high-profile cases with Germany as a target of Russian disinformation (Meister, 2016). Russian media operating in Germany, such as RT and Sputnik, have increasingly implanted disinformation into Germany's information environment, heightened by social media bots as well as social media users who repeatedly share the fake stories (Mortsiefer, 2018).

In June 2017, Germany passed the Network Enforcement Act or "NetzDG", focusing on raising accountability on online platforms (BBC, 2018; Thomasson, 2018). The law, which aims to combat hate speech and "fake news", underlines that "obviously illegal" posts need to be removed within 24 hours. YouTube, Facebook and Twitter as well as other sites with more than two million users in Germany risk fines of up to $€ 50$ million if they fail to oblige to this regulation. However, a key challenge of this law is that too much content was being blocked, resulting in curtailing free speech. Human rights activists and industry representatives criticised that the short and rigid time limit given forces social media companies to delete questionable posts in order 
to avoid penalties. In order to overcome this issue, officials considered revisiting the law, which includes recovering contents that are being deleted incorrectly, as well as having a third party organisation to review ambiguous posts (Thomasson, 2018).

In South East Asia, 5 countries are actively seeking for solutions to misinformation. Besides Malaysia, the other 4 countries are Singapore, Indonesia, Cambodia and the Philippines. Making no call for an urgent law, Singapore opted to thoroughly understand the ins and outs of disinformation, or what they call "deliberate online falsehood". They recently published a 300-pages parliamentary report where 22 approaches were proposed, gathering ideas from journalists, advocacy groups and several others as well as forming a committee (Koutsoukis, 2018). Singapore stresses the need to understand its scope, intent and powers (Idris, 2018).

Indonesia's approach involves multi-prong strategies. It recently formed a government agency called the National Cyber and Encryption Agency which actively implement site-tracking through blocking and removing fake content as well as utilising tools to automatically track and report sites with fake content (Batu, 2018a, 2018b; Kapoor, 2018). Its communications ministry has recently also announced the plans to hold weekly briefings on "fake news" fake news, in order to increase public awareness and educate them on the issue (Lamb, 2018b). Indonesia is also vigorously arresting alleged perpetrators, for instance, the Muslim Cyber Army (Lamb, 2018c). Further, ground-up independent efforts in Indonesia, through its civil society group Masyarakat Anti Fitnah Indonesia (Mafindo) for example, have also met great success. The group is consistently active in combatting false information online via its fact-checking Facebook group, offline public outreach, inclusive digital literacy as well as a variety of collaborations with journalists (Chua, 2018). Although consisting of only seven full-timers, the group successfully gained the cooperation of the public, reaching out to hundreds of volunteers across 17 Indonesian cities (Chua, 2018). 


\section{Moonyati Mohd Yatid}

Cambodia has recently introduced a new law to regulate media coverage that threatens national security. Under the law, someone who is found guilty of sharing false information could face imprisonment for up to two years with fines up to $\$ 1,000$ (Lamb, 2018a). Three ministries have been assigned to monitor media posts for potential violations. However, there are heightened concerns about the threats to personal freedoms in the lead up to the general elections (Lamb, 2018a).

Interestingly, an attempt by the Philippines to regulate against misinformation has resulted in a dismissed bill. The bill, which was filed by the Chair of the Senate's Committee, stated that government officials would be accountable for spreading false information, due to several politicians who have been accused of spreading disinformation for their own benefits (Elemia, 2018; Yap, 2018). The measure was, however, challenged as unconstitutional, disproportionately targeting on government officials and that traditionally, such a law could have never been passed (Philippines, 2017).

\section{Malaysia's Perspectives}

In this third section, discussions will be focused on Malaysia's perspectives. There are 4 sub-sections that will be discussed, namely on its digital landscape, the trend of misinformation, the current approaches being carried out in combatting the issue and lastly, on the way forward for Malaysia.

\section{Digital Landscape}

According to Malaysian Communications and Multimedia Commission (MCMC) Internet Users Survey 2017, 89\% of Malaysian users access the Internet via smart phone, which indicates that most Malaysians could access the Internet anytime and anywhere (Malaysian Communications and Multimedia Commission, 2017). The survey also found that the Top 3 activities for Malaysians on the Internet is to text, visit social media sites as well as look for information. Unfortunately, 
many users who find information online blindly believe what they read - the study found that $82.7 \%$ of users trusted health-related information found online, regardless of the source. Echoing global statistics, most Malaysians (89\%) obtain news online, and 72\% Malaysians obtain their news from social media. The survey also revealed that Malaysians actively engage on online platforms; $57 \%$ would share news to others via social media and email, and 30\% would comment on the news they read on social media or websites. Reuters' study showed that the top social media and messaging platforms in Malaysia are Facebook, WhatsApp and YouTube, as shown in Figure 3 (Nic Newman with Richard Fletcher \& Nielsen, 2018). Unfortunately, as revealed in another study, Malaysians are also increasingly confused and unable to differentiate real news from fake news (Ries, Bersoff, Armstrong, Adkins, \& Bruening, 2018).

\begin{tabular}{|c|c|c|c|c|}
\hline Rank & & Brand & For news & All \\
\hline$f$ & 1 & Facebook & $64 \%(+6)$ & $82 \%$ \\
\hline (1) & 2 & WhatsApp & $54 \%(+3)$ & $82 \%$ \\
\hline 需 & 3 & YouTube & $33 \%(+7)$ & $72 \%$ \\
\hline (0) & 4 & Instagram & $17 \%(+4)$ & $45 \%$ \\
\hline$y$ & 5 & Twitter & $13 \%(+3)$ & $25 \%$ \\
\hline (2) & 6 & Facebook Messenger & $12 \%(+1)$ & $36 \%$ \\
\hline
\end{tabular}

Figure 3. Top Social Media and Messaging Platforms (Source: Newman et.al, 2018, p.133)

\section{Misinformation Trend}

Many of the disinformation and misinformation in Malaysia are related to politics, religious, health and crime (Malaysia Communications and Multimedia Commission; "MCMC moves to curb fake news," 2017). For instance, leading up to and during the 2013 Malaysian General Election 


\section{Moonyati Mohd Yatid}

(GE), disinformation spread about how 40,000 Bangladeshi nationals who were brought to Malaysia to vote to help swing the votes to the benefit of the then ruling coalition. The impact of that disinformation was felt by those who looked like foreigners; they were confronted and manhandled at polling stations all over Malaysia(Szu, 2018).

In another example, a company was impacted financially when religious concerns were manipulated to jeopardise one's business. The shoe company Bata lost more than RM500,000 within a month, and forced to withdraw 70,000 pairs of shoes from 230 stores after false information about selling shoes with the Arabic word "Allah" on the soles of its shoes went viral ("Fake news leads to Bata losing \$158k in a month," 2017).

In terms of health-related "fake news", various information about the spread of hand, foot and mouth disease (HFMD), allegedly spreading all across Malaysia, had caused panic among the public in recent months (Malaysia Communications and Multimedia Commission). Crimerelated "fake news" also typically go viral, for instance, on a syndicate kidnapping hundreds of people and selling their organs in Sarawak (Malaysia Communications and Multimedia Commission).

Further, bots were identified as interfering in the recent GE in May 2018, where automated accounts flooded Twitter with tens of thousands of pro-government and anti-opposition messages. Two of the anti-opposition hashtags - '\#SayNoToPH' and '\#KalahkanPakatan' - were used around 44,100 times by 17,600 users in just the span of nine days to influence public opinion (Ananthalakshmi, 2018). It was also revealed that $98 \%$ of the users appear to be bots, according to a researcher from the Digital Forensic Research (DFR) Lab of the Atlantic Council think tank. Following the discovery, Twitter suspended hundreds of these accounts, where they were considered spam or malicious automation. The impact of this disinformation was considered minimal, as quoted by a new Minister of Pakatan Harapan, as the then ruling party had failed to win the $14^{\text {th }} \mathrm{GE}$. 
At present, Malaysia may face relatively minimal impacts of misinformation compared to other countries. However, due to the widening divide and deteriorating tolerance on religious, racial and sexual orientation issues, Malaysia may face bigger threats in the future if left unchecked.

\section{Approaches}

In terms of fighting misinformation and disinformation, Malaysia has carried out several strategies such as a new law, a fact-checking website and efforts to increase digital literacy, with the MCMC as one of the backbone agencies. In 2017 alone, there were 91 cases of false information were recorded. MCMC also took action against 3,721 fake accounts, out of which, more than $3 / 4$ of them were deleted from the various social media platforms (FMT, 2018).

MCMC is also in charge of establishing and maintaining a fact checking website called Sebenarnya.my, where it acts with ministries, government departments and agencies required to either verify or debunk any news involving them. However, there are concerns that this government-run approach might not be able to verify political issues, although these are one of the main trends of misinformation in Malaysia. This initiative should collaborate with various parties including non-governmental organisations (NGOs) and journalists to increase the trust level of society. It is important for fact-checking websites to reach out to the same audience as well as ensuring the society understands the truth. Several improvements could be a twoway communication website to further communicate with the public as well as usage of several languages to verify the news, especially when Malaysia is a multi-racial society. In another effort, MCMC has also held digital literacy programmes to increase awareness level for Malaysians. It was reported that in 2017, the programmes had reached about 1.5 million Malaysians (Ahmad, Yi, Shah, Tan, \& Chung, 2018). 


\section{Moonyati Mohd Yatid}

Besides the fact-checking website and digital literacy enhancement programmes, Malaysia has also passed the controversial Anti-Fake News Act, a law to deal with "fake news" and related matters. The Anti-Fake News Act, which was rushed through Parliament just in time for the GE, was criticised as a tool to stifle free speech, in particular on the 1MDB scandal (Beech, 2018). The law stated 'fake news' that include "any news, information, data and reports, which is or are wholly or partly false, whether in the form of features, visuals or audio recordings or in any other form capable of suggesting words or ideas". It also stated an offence to "maliciously create, offer, publish, print, distribute, circulate or disseminate any fake news, or publication containing fake news". The law also involves an extra-territorial application, which means that someone could be charged under the law regardless of his or her nationality and whether they are inside or outside Malaysia, so long as the 'fake news' are concerning Malaysia or Malaysians. While Germany's NetzDG puts the liability on social networks, Malaysia's Anti-Fake News Law puts the liability on individuals who are creator of the 'fake news'. The law's official justifications are to curb the creation and dissemination of fake news, protecting fake news victims as well as to maintain national security. Carrying stiff punishments, those who are found guilty serve up to six years in prison and a maximum fine of RM500,000 ("Anti Fake News Act 2018," 2018 ).

The first case under the law involves a Danish man disseminating disinformation about the Malaysian police through a Youtube video (Domonoske, 2018). Even the current Prime Minister, Tun Dr Mahathir Mohamed, was charged under the Anti-Fake News Act, regarding his claims of sabotage by the then ruling government towards him during the election period (Sidek, 2018).

Prior to the General Election, Pakatan Harapan had pledged to abolish several "oppressive" provisions in laws including the Anti-Fake News Act, if they won the Malaysian election. Thus, after the change of government in May 2018, the Parliament passed the bill to repeal the 
Act on $16^{\text {th }}$ Aug 2018 (Sivanandam, Carvalho, Rahim, \& Shagar, 2018). However, the upper house of Parliament, the Senate, rejected the AntiFake News Act Repeal soon after, on $12^{\text {th }}$ September 2018 ("Dewan Negara rejects Bill to repeal Anti-Fake News Act," 2018).

However, besides The Anti-Fake News Act, there are other existing legislative acts that could serve as promoting a safe cyber environment. Thus, many critiques argue whether the Anti-Fake News Act is necessary, given Malaysia has been using the other laws such as Printing Press and Publication Act 1984, Communications and Multimedia Act 1998, Sedition Act 1948, Defamation Act 1957 and Penal Code. However, due to the potential of bigger threats caused by disinformation and misinformation, Malaysia does need to review its existing laws and focus on the main intention the law is carried out and to manage a more specific impacts and understanding the motives behind those disinformation being spread. On $30^{\text {th }}$ September 2018, Communications and Multimedia Minister Gobind Singh said the government must press ahead to introduce hate speech laws, after a blogger allegedly racist remarks about a police of Sikh descent have gone viral and offended the Sikh community (AR, 2018).

\section{Way Forward}

The impact of "fake news" on Malaysia could still be considered as relatively "mild", although the country may face a bigger threat in the future if the problem is not addressed accordingly. Moving forward, the paper identifies four areas of improvements for Malaysia to further strengthen its approach combatting disinformation and misinformation.

\section{Enhancing Legal Responses}

As described earlier, Malaysia's Parliament decision to repeal the Anti-Fake News Act has recently been rejected by the Malaysian Senate ("Dewan Negara rejects Bill to repeal Anti-Fake News Act," 2018). Thus the debate of whether this Act is beneficiary for the country is still on- 


\section{Moonyati Mohd Yatid}

going. Many believes that the Act is politically motivated, established by the then ruling government to suppress public opinion (Beech, 2018). Arguments also linger around its necessity, given that there is a string of existing Acts that could arguably support the justification of the AntiFake News Act's establishment. The stiff punitive measures, as well as the loose definition of "fake news" have also created public concerns. This Act has also reinforced Malaysia's image as an authoritarian country. A study by local open technology initiative Sinar Project and global censorship monitor Open Observatory of Network Interference (OONI) in 2016 revealed that 35 percent of Internet censorship was on pornography, 25 percent on gambling $12.5 \%$ on news sites and 10 percent on political criticism (Xynou, Filastò, Yusof, \& Ming, 2016).

In reviewing the Anti-Fake News Act, the Pakatan Harapan-led "New Malaysia" should look closely into the function of this law, the definition of "fake news", the degree of the impact, the motive of creating and spreading false information and lastly, the responsible parties. Understanding all these elements would enable Malaysia to successfully revise the Anti-Fake News Act - maximising efforts against misinformation. The Pakatan Harapan Government also needs to eliminate the negative perception the public has towards laws that regulate content, by eradicating elements of politics and focus solely on combatting the problem.

\section{Developing Digital Literacy}

In 2017, Malaysia's MCMC reached out to 1.5 million Malaysians for its awareness programmes in combatting false information online. Ideally, this awareness programme should be reached out to all layers of society. More discussions and talks should be carried out to ensure society is not only aware of the danger and impact of disinformation, but also to make them realise the importance of checking facts before spreading information online. Critical thinking and the desire for truth is key. Readers should learn how to carry out investigative research 
on their own through fact-checking websites and background check of sources. Further, Malaysian media should embrace the principles of professionalism and integrity to produce high quality news. They should avoid sensationalised, harmful stories or irresponsibly republishing news from other sources. Nurturing a society that is critical of information will create a demand for quality information to be produced by the media.

\section{Heightening The Accountability of Social Media Platforms}

The fight against disinformation and misinformation is a fight by all, including social media platforms. As the Indian Law and IT Minister Ravi Shankar Prasad from puts it, "Social Media could not continue being a mute spectator anymore" ("Govt says WhatsApp cannot be a mute spectator," 2018). Recently, increasing efforts by social media platforms could be observed including overhauls of platforms and introducing new functions to fight against dis/misinformation. For instance, one of Facebook's initiatives involved automated systems identifying duplicates of misinformation flagged previously (Drozdiak, 2018). Facebook has also launched and shared what they call "Understanding the Facebook Community Standards Enforcement Report" (Schultz \& VP, 2018) for more transparency between them and the public in terms of their initiatives and efforts. Recently WhatsApp has introduced its 'Forward' function, to increase public awareness on the possibility of those forwarded messages being false information. The function also limits the number of recipients and in countries such as India, where disinformation via WhatsApp is rampant, the limit is much lower ("WhatsApp to limit forwarding messages in India after mob lynchings," 2018). WhatsApp even offers monetary incentives for ideas on how to fight false information on its platform, where the solutions could be different from open network such as Facebook and YouTube ("WhatsApp Launches Research Grants To Fight Fake News - Offering Up To \$50,000 Per Proposal," 2018). Although just a plan, 


\section{Moonyati Mohd Yatid}

Youtube has recently also joined the bandwagon, announcing its plans involving recommendation engine to push news-related videos from reputable outlets and "link-shame" videos containing false information (Vega, 2018).

The question remains however, if these efforts are enough? And while initiatives might differ according to requirements and cooperation by countries, Malaysia could look into other ways of how social media and instant messaging platforms can combat misinformation and disinformation. Some believe that these platforms need to step up their role of news publishers, as self-regulation and accountability are needed. Else, countries might need to follow the footsteps of Germany. As described in this paper's section on 'States Responses in Countering Disinformation and Misinformation', Germany's NetzDG law puts the liability on online platforms that risks facing hefty fines if they fail to take down posts with elements of hate speech or 'fake news'. It is worth noting, however, that the controversial new law has turned into a proving ground for whether tech giants could be depended on to overcome a major task - differentiating between free speech and misinformation, especially hate speech.

\section{Strengthening The Fact-Checking Mechanism}

Malaysia already established a fact-checking mechanism through its website 'Sebenarnya.my' with its tagline "Tak Pasti Jangan Kongsi", which translates into "when in doubt, do not share". Fact-checkers are great to level the informational field but the impact of their contributions will be dependent on the integrity of the institution. The task is not easy as it also involves correcting worldviews which is highly correlated with thinking patterns and pulling individuals out of echo chambers. Benchmarking with fact-checking mechanism in other countries, Malaysia may enhance its approach by considering these following points: 1) Two-way communication between fact-checkers and the public 2) Expanding its reach via multiple language as the medium of 
communication 3) Involving of independent bodies, journalists and volunteers from the public, beyond government agencies in debunking false information 4) Encourage other organisations to establish its own fact-checking mechanism 5) Rather than being reactive towards reports, proactively identify "fake news" through flagging with the help of artificial intelligence.

\section{Conclusion}

In conclusion, the spread of false information, described academically as disinformation and misinformation, is not a new phenomenon. However, social media facilitates the proliferation of false information, thereby affecting how societies view the world. The impact of false information is alarming and becoming a global concern. Many countries are taking actions against it by proposing new laws, forming taskforces and enhancing digital literacy.

Malaysia's efforts in combatting the problem of online falsehood include a series of laws to promote a safe cyber environment, the newly introduced Anti-Fake News Act, awareness programs and a fact-checking website to debunk false information. However, there is room for improvement to address the problems in protecting and stabilizing the information ecosystem. There are four proposed areas of improvement: 1) enhancing current legal responses 2) developing digital literacy 3) heightening the accountability of social media platforms, 4) strengthening the fact-checking mechanism.

\section{References}

Ahmad, R., Yi, T. X., Shah, M. F., Tan, T., \& Chung, C. (2018). Anti-fake news portal extends reach with app and social media. The Star Online Retrieved from https://www.thestar.com.my/news/ nation/2018/03/07/antifake-news-portal-extends-reach-withapp-and-social-media/ 


\section{Moonyati Mohd Yatid}

Ananthalakshmi, A. (2018). Ahead of Malaysian polls, bots flood Twitter with pro-government messages. Reuters Retrieved from https://www.reuters.com/article/us-malaysia-electionsocialmedia/ahead-of-malaysian-polls-bots-flood-twitter-withpro-government-messages-idUSKBN1HR2AQ

Anti Fake News Act 2018, (2018).

AR, Z. (2018). After blogger's racist remark, Gobind wants anti-hate speech laws with global reach. Malay Mail. Retrieved from https:// www.malaymail.com/s/1677981/after-bloggers-racist-remarkgobind-wants-anti-hate-speech-laws-with-global

Azali, K. (2017). Fake News and Increased Persecution in Indonesia. In I. Y. I. Institute (Ed.), (Vol. 61).

Baker, H., \& Capestany, C. (2018). It's Getting Harder to Spot a Deep Fake Video. Bloomberg.

Batu, S. L. (2018a). Govt deploys artificial intelligence to combat internet hoaxes. The Jakarta Post Retrieved from http://www. thejakartapost.com/news/2018/01/31/govt-deploys-artificialintelligence-to-combat-internet-hoaxes.html

. (2018b). Nine social media, messaging apps agree to combat fake news. The Jakarta Post. Retrieved from http://www. thejakartapost.com/news/2018/01/31/nine-social-mediamessaging-apps-agree-to-combat-fake-news.html

BBC. (2018). Germany starts enforcing hate speech law. $B B C$.

Beech, H. (2018). As Malaysia Moves to Ban 'Fake News,' Worries About Who Decides the Truth. The New York Times Retrieved from https://www.nytimes.com/2018/04/02/world/asia/malaysiafake-news-law.html

Bengali, S. (2018). Fake news on WhatsApp is getting people killed in India. The Star. Retrieved from https://www.thestar.com/news/ world/2018/05/31/fake-news-on-whatsapp-are-getting-peoplekilled-in-india.html 
Burgess, M. (2018). To fight fake news on WhatsApp, India is turning off the internet. WIRED. Retrieved from https://www.wired.co.uk/ article/whatsapp-web-internet-shutdown-india-turn-off

Centre, C. D. O. (2018). 10 Kategori Berita Tidak Benar dan Mengelirukan. Retrieved from http://www.mod.gov.my/images/mindef/ banner/berita-mengelirukan.pdf

Chua, A. (2018). The Big Read: In the war against fake news, public needs to get in the trenches. TODAY Retrieved from https://www. todayonline.com/singapore/big-read-war-against-fake-newspublic-needs-get-trenches

Commission, M. C. a. M. Sebenarnya.my

Commission, M. C. a. M. (2017). Internet Users Survey 2017. Retrieved from

Dewan Negara rejects Bill to repeal Anti-Fake News Act. (2018). The Star Retrieved from https://www.thestar.com.my/news/ nation/2018/09/12/dewan-negara-rejects-bill-to-repeal-antifake-news-act/\#w8yxqpfSJvDVhS1D.99

Domonoske, C. (2018). Danish Man Is First Person Sentenced Under Malaysia's Anti-Fake-News Law. npr. Retrieved from https:// www.npr.org/sections/thetwo-way/2018/04/30/607068241/ danish-man-is-first-person-convicted-under-malaysias-anti-fakenews-law

Drozdiak, N. (2018). Facebook's fight with fake news gets helping hand from robots. The Star.

Economy, P. R. o. I. s. C. (2016). 'Household Survey on India's Citizen Environment \& Consumer Economy' (ICE 360 survey). Retrieved from

Elemia, C. (2018). Duterte is no. 1 source of fake news - veteran journalist. Rappler Retrieved from https://www.rappler.com/ nation/194838-duterte-top-source-fake-news-journalist-ellentordesillas 


\section{Moonyati Mohd Yatid}

Fake news leads to Bata losing \$158k in a month. (2017). The Straits Times Retrieved from https://www.straitstimes.com/global

FMT. (2018). 91 cases of spreading 'fake news' recorded last year. Free Malaysia Today Retrieved from https://www.freemalaysiatoday. com/category/nation/2018/03/13/91-cases-of-spreading-fakenews-recorded-last-year/

Funke, D. (2018). A guide to anti-misinformation actions around the world. Retrieved from https://www.poynter.org/news/guideanti-misinformation-actions-around-world

Gabbatt, A. (2018). How Trump's 'fake news' gave authoritarian leaders a new weapon. The Guardian Retrieved from https://www. theguardian.com/us-news/2018/jan/25/how-trumps-fakenews-gave-authoritarian-leaders-a-new-weapon

Gearhart, S., \& Zhang, W. (2014). Gay bullying and online opinion expression: Testing spiral of silence in the social media environment. Social science computer review, 32(1), 18-36.

Govt says WhatsApp cannot be a mute spectator. (2018). Deccan Herald. Retrieved from https://www.deccanherald.com/national/moblynchings-govt-asks-682309.html

Hasher, L., Goldstein, D., Toppino, T. J. J. o. v. l., \& behavior, v. (1977). Frequency and the conference of referential validity. 16(1), 107112.

Head, J. (2017). Myanmar conflict: Fake photos inflame tension. $B B C$. Retrieved from https://www.bbc.com/news/worldasia-41123878

Idris, A. A. (2018). Singapore in 'no rush' to impose fake news law. Asian Correspondent Retrieved from https://asiancorrespondent. com/2018/06/singapore-fake-news/\#TLdm2R3kFHDQZ3kz.97

Kapoor, K. (2018). Indonesia's new cyber agency looks to recruit staff of hundreds. Reuters. Retrieved from https://www.reuters.com/ article/us-indonesia-cyber/indonesias-new-cyber-agency-looksto-recruit-staff-of-hundreds-idUSKBN1EU15X 
Koutsoukis, J. (2018). Singapore Set to Tackle Spread of Fake News With New Laws. Bloomberg Retrieved from https://www.bloomberg. com/news/articles/2018-09-20/singapore-set-to-tackle-spreadof-fake-news-with-new-laws

Lamb, K. (2018a). Cambodia 'fake news' crackdown prompts fears over press freedom. The Guardian Retrieved from https://www. theguardian.com/world/2018/jul/06/cambodia-fake-newscrackdown-prompts-fears-over-press-freedom?CMP=share_btn_tw (2018b). Indonesian government to hold weekly 'fake news' briefings. The Guardian Retrieved from https://www.theguardian. com/world/2018/sep/27/indonesian-government-to-holdweekly-fake-news-briefings

. (2018c). Muslim Cyber Army: a 'fake news' operation designed to derail Indonesia's leader. The Guardian Retrieved from https://www.theguardian.com/world/2018/mar/13/ muslim-cyber-army-a-fake-news-operation-designed-to-bringdown-indonesias-leader

Lees, C. J. I. o. C. (2018). Fake news: the global silencer: The term has become a useful weapon in the dictator's toolkit against the media. Just look at the Philippines. 47(1), 88-91.

Lind, D. (2018). President Donald Trump finally admits that "fake news" just means news he doesn't like. Vox. Retrieved from https://www. vox.com/policy-and-politics/2018/5/9/17335306/trump-tweettwitter-latest-fake-news-credentials

MCMC moves to curb fake news. (2017). The Star Online

Meister, S. (2016). The "Lisa Case" - Germany as a target of Russian Disinformation. NATO Review . Retrieved from https://www.nato. int/docu/review/2016/also-in-2016/lisa-case-germany-targetrussian-disinformation/EN/index.htm

Meserole, C. (2018). How misinformation spreads on social mediaAnd what to do about it. In T. B. Institution (Ed.). Retrieved from https://www.brookings.edu/about-us/ 


\section{Moonyati Mohd Yatid}

Morin, R. (2018). Trump labels media 'the opposition party' as newspapers push back en masse. Politico. Retrieved from https:// www.politico.com/story/2018/08/16/trump-calls-media-fakenews-as-newspapers-push-back-against-claim-779555

Mortsiefer, M. (2018). The German Battle with Fake News. Readings No.1. Eastern Europe Studies Centre. Retrieved from http://www. eesc.lt/uploads/news/id1059/Readings\%202018\%201.pdf

Nic Newman with Richard Fletcher, A. K., \& Nielsen, D. A. L. L. a. R. K. (2018). Reuters Institute

Digital News Report2018 Retrieved from http://media.digitalnewsreport. org/wp-content/uploads/2018/06/digital-news-report-2018. pdf?x89475

Noelle-Neumann, E. J. J. o. c. (1974). The spiral of silence a theory of public opinion. 24(2), 43-51.

Oliver, P. (2018). The State of Disinformation on Social Media. NYU Center for Data Science. Retrieved from https://medium.com/ center-for-data-science/the-state-of-disinformation-on-socialmedia-397d3c30f56a

Philippines, C. (2017). Duterte: Law against fake news won't be passed. CNN Philippines. Retrieved from http://cnnphilippines.com/ news/2017/10/04/Duterte-Law-against-fake-news-wont-bepassed.html

PTI. (2018). Maharashtra: Two men lynched in Aurangabad district on suspicion of being robbers. Indian Express. Retrieved from http:// www.newindianexpress.com/nation/2018/jun/13/maharashtratwo-men-lynched-in-aurangabad-district-on-suspicion-of-beingrobbers-1827738.html

Ries, T. E., Bersoff $\backslash$, D. M., Armstrong, C., Adkins, S., \& Bruening, J. (2018). 2018 Edelman Trust Barometer. Retrieved from

Safi, M. (2018). https://www.theguardian.com/world/2018/apr/03/ revealed-facebook-hate-speech-exploded-in-myanmar-duringrohingya-crisis. The Guardian. Retrieved from https://www. 
theguardian.com/world/2018/apr/03/revealed-facebook-hatespeech-exploded-in-myanmar-during-rohingya-crisis

Saldanha, A., Rajput, P., \& Hazare, J. (2018). Child-Lifting Rumours: 33 Killed In 69 Mob Attacks Since Jan 2017. Before That Only 1 Attack In 2012. Retrieved from

Sanghvi, V. (2018). India's Lynching App: Who Is Using Whatsapp As A Murder Weapon? South China Morning Post. Retrieved from https://www.scmp.com/week-asia/society/article/2154436/ indias-lynching-app-who-using-whatsapp-murder-weapon

Schultz, A., \& VP, G. R. (2018). Understanding the Facebook Community Standards Enforcement Report. Retrieved from

Shu, K., Sliva, A., Wang, S., Tang, J., \& Liu, H. J. A. S. E. N. (2017). Fake news detection on social media: A data mining perspective. 19(1), 22-36.

Sidek, H. (2018). Tun M investigated for 'fake news'. New Straits Times Retrieved from https://www.nst.com.my/news/ politics/2018/05/364869/tun-m-investigated-fake-news

Silverman, C. (2016). This Analysis Shows How Viral Fake Election News Stories Outperformed Real News On Facebook. BuzzFeed. Retrieved from https://www.buzzfeednews.com/article/craigsilverman/viralfake-election-news-outperformed-real-news-on-facebook

Sivanandam, H., Carvalho, M., Rahim, R., \& Shagar, L. K. (2018). Parliament passes bill to repeal Anti-Fake News law. The Star Retrieved from https://www.thestar.com.my/news/nation/2018/08/16/ parliament-passes-bill-to-repeal-anti-fake-news-law/

Steinberg, L. (2017). Beyond Fake News - 10 Types of Misleading News Retrieved from https://eavi.eu/beyond-fake-news-10-typesmisleading-info/

Subramanian, S. (2017). Inside The Macedonian Fake-News Complex. Wired.

Szu, K. V. (2018). Mysay: Fake news and more fake news. The Edge Markets. Tandoc Jr, E. C., Lim, Z. W., \& Ling, R. J. D. J. (2018). Defining "fake news" A typology of scholarly definitions. 6(2), 137-153. 


\section{Moonyati Mohd Yatid}

Thomasson, E. (2018). Germany looks to revise social media law as Europe watches. Reuters. Retrieved from https://www.reuters. com/article/us-germany-hatespeech/germany-looks-to-revisesocial-media-law-as-europe-watches-idUSKCN1GK1BN

Vega, N. (2018). YouTube will 'link-shame' fake news and hoax videos. New York Post. Retrieved from https://nypost.com/2018/03/14/ youtube-will-link-shame-fake-news-and-hoax-videos/

Vosoughi, S., Roy, D., \& Aral, S. J. S. (2018). The spread of true and false news online. 359(6380), 1146-1151.

Wardle, C., \& Derakhshan, H. J. C. o. E. r., DGI. (2017). Information Disorder: Toward an interdisciplinary framework for research and policymaking. 9 .

WeAreSocial, \& Hootsuite. (2018). 2018 Global Digital. Retrieved from Wendling, M. (2018). The (almost) complete history of 'fake news'. $B B C$ News Retrieved from https://www.bbc.com/news/blogstrending-42724320

WhatsApp Launches Research Grants To Fight Fake News - Offering Up To \$50,000 Per Proposal. (2018). Huffington Post Retrieved from https://www.huffingtonpost.in/2018/07/09/whatsapplaunches-research-grants-to-fight-misinformation-offering-upto-50-000-per-proposal_a_23477400/

WhatsApp to limit forwarding messages in India after mob lynchings. (2018). DW. Retrieved from https://www.dw.com/en/ whatsapp-to-limit-forwarding-messages-in-india-after-moblynchings/a-44757297

Xynou, M., Filastò, A., Yusof, K., \& Ming, T. S. (2016). The State of Internet Censorship in Malaysia. Retrieved from https://ooni.torproject. org/post/malaysia-report/

Yap, C. (2018). Duterte Decries 'Fake News' as Critics Warn of Media Crackdown. Bloomberg. Retrieved from https://www.bloomberg. com/news/articles/2018-01-17/duterte-hits-fake-news-ascritics-warn-of-media-crackdown 